\title{
FAKTOR-FAKTOR YANG MEMITIGASI FINANCIAL DISTRESS PADA PERUSAHAAN PERTAMBANGAN
}

\author{
Gita Wahyuningsih Putri \\ gitawahyuningsihp@student.telkomuniversity.ac.id \\ Wiwin Aminah \\ Fakultas Ekonomi dan Bisnis, Universitas Telkom
}

diterima: 27/12/2017; direvisi: 30/1/2018; diterbitkan: 30/4/2019

\begin{abstract}
Gross export growths in the mining sector have experienced negatively for the last few years. One of the negative impact is the reduce of revenue generated in the mining sector causing some companies gain negative profit that can trigger financial distress. This research goal is to know the effect of liquidity, activity, growth, board of directors, and audit committee give impact to the financial distress in the mining companies that listed on IDX in the period of 2011-2016. The research sample was collected by purposive sampling method in order to obtain 24 companies. Logistic regression analysis is also used to be the method of this research. The results showed that liquidity, activity, growth, board of directors and audit committee have simultaneous significant effect, but at the same time, liquidity and activities have partial significant effect to the condition of financial distress.
\end{abstract}

Keywords: financial distress; liquidity; activity; growth; board of directors; audit committee

\begin{abstract}
Abstrak
Pertumbuhan ekspor sektor pertambangan dalam beberapa tahun terakhir mengalami pertumbuhan negatif. Hal tersebut memberikan dampak negatif yaitu berkurangnya pendapatan sektor pertambangan yang dihasilkan sehingga menyebabkan beberapa perusahaan pertambangan memiliki laba negatif sehingga dapat memicu terjadinya kondisi financial distress. Penelitian ini bertujuan untuk mengetahui pengaruh likuiditas, aktivitas, pertumbuhan, dewan direksi, dan komite audit terhadap financial distress pada perusahaan pertambangan yang terdaftar di BEI periode 2011-2016. Sampel penelitian ditentukan oleh metode purposive sampling sehingga memperoleh 24 perusahaan. Metode analisis yang digunakan adalah analisis regresi logistik. Hasil penelitian menunjukkan likuiditas, aktivitas, pertumbuhan, dewan direksi, dan komite audit secara simultan berpengaruh signifikan, akan tetapi secara parsial likuiditas dan aktivitas berpengaruh terhadap kondisi financial distress.
\end{abstract}

Kata Kunci : financial distress; likuiditas; aktivitas; pertumbuhan; dewan direksi; komite audit 


\section{PENDAHULUAN}

Sejak tahun 2012-2015 pertumbuhan sektor pertambangan terus mengalami penurunan, hal ini dapat dilihat dari pertumbuhan domestik bruto yang dihasilkan oleh sektor pertambangan Menurut BPS (2017), tahun 2016 makin memperpanjang tren penurunan ekspor Indonesia. Artinya, sudah lima tahun berturut-turut ekspor Indonesia terus menurun atau tumbuh negatif. Faktor eksternal terjadinya penurunan ekspor di Indonesia antara lain lesunya perekonomian global dan jatuhnya harga komoditas. Lesunya perekonomian global menyebabkan transaksi perdagangan dunia menurun. Akibatnya, permintaan barang dari Indonesia juga menyusut.

Menurut BPS (2017), tahun 2016 makin memperpanjang tren penurunan ekspor Indonesia yang terjadi sejak tahun 2012-2016. Artinya, sudah lima tahun berturut-turut ekspor Indonesia terus menurun atau tumbuh negatif. Faktor eksternal terjadinya penurunan ekspor di Indonesia antara lain lesunya perekonomian global dan jatuhnya harga komoditas. Lesunya perekonomian global menyebabkan transaksi perdagangan dunia menurun. Akibatnya, permintaan barang dari Indonesia juga menyusut. Selain dampak dari perlambatan ekonomi global maupun domestik, faktor lain yang mempengaruhi yaitu kebijakan negara mengenai Undang-Undang Mineral dan Batubara No. 4 tahun 2009 yang mulai berlaku 12 Januari 2014 tentang pemerintah menetapkan larangan ekspor bahan mentah yang mengakibatkan tidak sedikitnya perusahaan pertambangan mengalami dampak regulasi.

Menurut Andriyanto (2015), anjloknya harga minyak dunia tertajam di tahun 2014, para pengamat mengatakan turunnya harga-harga itu disebabkan melimpahnya pasokan di pasar dunia yang disebabkan oleh berbagai faktor yaitu AS dan Kanada telah meningkatkan produksi minyak mereka, berkat teknologi fracking yang memungkinkan perusahaan-perusahaan pengeboran mencapai endapan minyak yang sebelumnya tidak terjangkau. Produksi minyak AS mencapai 9 juta barel per hari, tingkat tertinggi dalam lebih dari 30 tahun.Pada waktu bersamaan, pertumbuhan ekonomi melamban di Tiongkok, konsumen energi terbesar di dunia. Hal tersebut berdampak ke perusahaan-perusahaan pertambangan yang ada di Indonesia.

Faktor lain menyebutkan bahwa Djumena (2015), menyatakan pada tahun 2015 krisis perekonomian global semakin akut. Perusahaan di bidang pertambangan dan perkebunan paling parah terkena dampaknya. Sebanyak kurang lebih 125 perusahaan pertambangan batu bara di Kalimantan Timur tidak beroperasi. Akibatnya, 5.000 orang terkena pemutusan hubungan kerja (PHK). PHK terjadi karena terdapat $80 \%$ perusahaan tambang khususnya batu bara yang memberhentikan produksinya dan tutup sementara, sebagian besar yang tutup adalah perusahaan kecil di daerah pertambangan, seperti Kalimantan. Hal tersebut dikarenakan harga jual batubara yang rendah sehingga perusahaan tidak dapat menutupi biaya produksi dan menyebabkan perusahaan mengalami kerugian.

Dari faktor-faktor tersebut memberikan dampak negatif bagi sektor pertambangan, yaitu berkurangnya pendapatan yang dihasilkan sehingga menyebabkan beberapa perusahaan pertambangan memiliki laba negatif sehingga memicu terjadinya kondisi financial distress. Perusahaan yang mengalami kesulitan keuangan penyebabnya yaitu memiliki kinerja keuangan dan mekanisme good corporate governance yang kurang baik. Hal tersebut dapat dilihat dari kejadian pada perusahaan yaitu pengurangan dividen, pabrik yang ditutup, adanya kerugian, pemberhentian kerja (PHK), mundurnya CEO perusahaan dan harga saham yang merosot tajam.

Menurut Hamdani (2017), salah satu perusahaan yang tidak mampu membagikan deviden yaitu PT Bumi Resources Minerals Tbk (BRMS). BMRS dalam rapat umum pemegang saham tahunan (RUPST) dan rapat umum pemegang saham luar biasa (RUPS-LB) memutuskan tak membagikan dividen. Komisaris Utama BMRS Ari S. Hudaya menjelaskan, tak dibagikannya dividen kepada pemegang saham karena kinerja keuangan perseroan masih mengalami kerugian. Menurut Brigham dan Houston (2010), rasio keuangan dirancang untuk membantu kita mengevaluasi laporan keuangan. Rasio-rasio keuangan sering kali digunakan untuk memprediksi kondisi financial distress pada suatu perusahaan, yang mana dapat dilihat di dalam laporan keuangan yang diterbitkan oleh perusahaan.

Menurut Hermawan (2013), selain rasio keuangan corporate governance juga dapat digunakan untuk memprediksi kondisi financial distress pada suatu perusahaan, yang mana informasi mengenai mekanisme corporate governance dapat dilihat di dalam laporan keuangan tahunan yang diterbitkan oleh perusahaan.

Financial distress, menurut Platt dan Platt (2002), financial distress sebagai tahap penurunan kondisi keuangan yang terjadi sebelum terjadinya kebangkrutan atau likuidasi. Menurut Fahmi (2012:93), financial distress dimulai dari ketidakmampuan dalam memenuhi kewajiban-kewajibannya, terutama kewajiban yang bersifat jangka pendek termasuk kewajiban likuiditas, dan juga termasuk kewajiban dalam kategori solvabilitas. Perusahaan yang sedang mengalami kesulitan keuangan (financial distress) dapat dilihat dari kejadian pada perusahaan yaitu pengurangan dividen, pabrik yang ditutup, adanya kerugian, pemberhentian kerja (PHK), mundurnya CEO perusahaan dan harga saham yang merosot tajam, Whitaker dalam Manurung (2012:96).

Dari definisi tersebut, peneliti menarik kesimpulan bahwa financial distress merupakan suatu kondisi kesulitan keuangan dalam perusahaan berupa penuruan perolehan laba, ketidakmampuan perusahaan dalam melunasi hutang serta kewajiban yang disajikan 
berdasarkan laporan keuangan dengan membandingkan laporan keuangan periode sebelumnya.

Perusahaan yang mengalami kesulitan keuangan penyebabnya yaitu memiliki kinerja keuangan dan mekanisme good corporate governance yang kurang baik. Hal tersebut dapat dilihat dari kejadian pada perusahaan yaitu pengurangan dividen, pabrik yang ditutup, adanya kerugian, pemberhentian kerja (PHK), mundurnya $\mathrm{CEO}$ perusahaan dan harga saham yang merosot tajam. Berdasarkan gabungan dari beberapa ahli tersebut, terdapat bentuk-bentuk rasio keuangan yang penulis gunakan untuk menghitung serta menilai kondisi keuangan suatu organisasi atau perusahaan khususnya untuk melihat apakah suatu perusahaan mengalami kondisi financial distress atau tidak yaitu dengan menggunakan likuiditas, aktivitas, dan pertumbuhan penjualan.

Menurut Fahmi (2012:59), likuiditas merupakan kemampuan perusahaan memenuhi kewajiban jangka pendeknya secara tepat waktu. Jika suatu perusahaan mengalami masalah likuiditas maka sangat memungkinkan perusahaan tersebut mulai memasuki masa kesulitan keuangan (financial distress) yang dintandai dengan ketidakmampuan perusahaan dalam memenuhi kewajiban-kewajiban jangka pendeknya dan jika kondisi kesulitan tersebut tidak cepat diatasi maka akan berdampak pada kebangkrutan usaha (bankruptcy). Hasil penelitian ini didukung oleh Widhari dan Merkusiwati (2015) yang menyatakan bahwa rasio likuiditas yang dihitung menggunakan current ratio berpengaruh negatif terhadap kondisi financial distress perusahaan. Hal tersebut menunjukkan jika current ratio yang dimiliki perusahaan menurun maka probabilitas financial distress perusahaan akan meningkat ataupun sebaliknya. Hal tersebut menunjukkan bahwa semakin tinggi likuiditas yang dimiliki perusahaan maka semakin kecil kemungkinan perusahaan mengalami financial distress.

Menurut Fahmi (2012:65), rasio aktivitas adalah rasio yang digunakan untuk mengukur tingkat efisiensi atas pemanfaatan sumber daya yang dimiliki perusahaan, atau untuk menilai kemampuan perusahaan dalam menjalankan aktivitasnya seharihari. Rasio ini merupakan ukuran seberapa jauh aktiva telah dipergunakan dalam kegiatan perusahaan dan untuk melihat keefektifan perputaran seluruh aset perusahaan. Apabila perusahaan tidak dapat memaksimalkan perputaran aset yang dimiliki maka kemungkinan penjualan akan menurun, jika penurunan ini terus menerus terjadi kemungkinan perusahaan akan memperoleh hasil maksimal akan semakin kecil bahkan bisa berakibat kerugian. Jika hal ini tidak dapat diatasi maka perusahaan akan mengalami financial distressdan sebaliknya. Semakin tinggi atau semakin sering perputaran aset terjadi maka kemungkinan perusahaan mengalami financial distress akan semakin kecil. Dalam penelitian ini peneliti dapat memprediksi bahwa aktivitas dengan proksi total asset turnover berpengaruh negatif terhadap financial distress.

Widhiari dan Merkusiwati (2015) melakukan penelitian mengenai pengaruh pertumbuhan penjualan terhadap financial distress, penelitian tersebut menunjukkan hasil pertumbuhan memiliki pengaruh negatif signifikan terhadap financial distress. Hal tersebut menunjukkan bahwa tingginya tingkat pertumbuhan penjualan mengindikasikan perolehan laba yang besar. Apabila tingkat pertumbuhan penjualan suatu perusahaan tinggi berarti tercermin kondisi keuangan yang cukup stabil dan terhindar darifinancial distress, karena terbukti dengan penjualan yang dapat terus bertumbuh setiap tahunnya.

Apabila perusahaan mampu untuk meningkatkan penjualan dari tahun ke tahun maka kemungkinan perusahaan untuk memperoleh hasil yang maksimal akan semakin besar sehingga berdampak pada meningkatnya pendapatan perusahaan sehingga perusahaan dapat terhindar dari kondisi financial distress.

Dewan direksi merupakan salah satu mekanisme corporate governance yang diperlukan untuk mengurangi agency problem antara pemilik dan manajer sehingga timbul keselarasan kepentingan antara pemilik perusahaan dan manajer. Pada penelitian ini penulis memprediksi bahwa dewan direksi berpengaruh negatif signifikan terhadap financial distress. Hal tersebut menunjukkan bahwa semakin besar jumlah dewan direksi, maka diharapkan akan semakin baik pula kualitas keputusan yang dihasilkan. Dampaknya akan berpengaruh pada kinerja perusahaan yang dapat menekan potensi kesulitan keuangan di masa depan.

Sesuai dengan teori keagenan, kualitas pengawasan yang baik dapat menurunkan perilaku oportunistik yang dilakukan oleh manajer sebagai agen. Pada penelitian ini penulis memprediksi bahwa komite audit dengan proksi jumlah komite audit berpengaruh negatif terhadap financial distress. Terciptanya fungsi pengawasan komite audit yang efektif berhubungan dengan jumlah sumber daya yang dimiliki oleh komite. Efektivitas komite audit akan meningkat jika ukuran komite meningkat, karena komite memiliki sumber daya lebih untuk menangani masalah-masalah yang dihadapi oleh perusahaan. Komite audit merupakan pilar penting dalam penerapan good corporate governance, karena komite audit juga berperan dalam evaluasi laporan keuangan (Zarkasyi, 2008:22). Oleh karena itu, diharapkan keberadaan komite audit yang efektif dapat mengubah kebijakan yang berbeda dalam pencapaian laba akuntansi pada beberapa tahun ke depan sehingga perusahaan dapat menghindari terjadinya permasalahan keuangan. Hal tersebut sejalan dengan penelitian Hanifah (2013), yang menyatakan bahwa komite audit merupakan mekanisme corporate governance yang diasumsikan mampu mengurangi masalah keagenan yang timbul pada suatu perusahaan. Kerangka pemikiran digambarkan dalam Gambar 1. 


\section{METODE}

Metode yang digunakan dalam penelitian ini adalah metode analisis regresi logistik dan menggunakan analisis statistik deskriptif. Operasionalisasi ditunjukkan pada Tabel 1. Populasi yang digunakan adalah perusahaan pertambangan yang terdaftar di BEI tahun 2011-2016 menggunakan teknik purposive sampling dengan kriteria yaitu: 1) Perusahaan sektor pertambangan yang konsisten terdaftar di BEI, 2) Perusahaan sektor pertambangan yang mempublikasikan laporan keuangan diaudit secara konsisten tahun 2011-2016, 3) Perusahaan pertambangan yang memiliki data lengkap. Data yang diperoleh sebanyak 144 yang terdiri dari 24 perusahaan dengan periode penelitian selama enam tahun. Metode analisis yang digunakan adalah analisis regresi logistik.

\section{HASIL}

Berdasarkan Tabel 2 dapat diketahui bahwa nilai minimum likuiditas adalah sebesar 0,0524 artinya setiap satu rupiah utang lancar perusahaan dijamin oleh 0,0524 aset lancar perusahaan. Nilai maksimum likuiditas adalah sebesar 10,6423 artinya setiap satu rupiah utang lancar perusahaan diwakili oleh 10,6423 aset lancar perusahaan. Nilai rata-rata tingkat likuiditas sebesar 1,9445 sedangkan nilai standar deviasi sebesar 1,3382, nilai rata-rata likuiditas lebih besar dari nilai standar deviasi. Hal ini menunjukkan bahwa data likuiditas dalam penelitian ini tidak bervariasi atau data berkelompok.

Aktivitas memiliki nilai minimum 0,0018 artinya dalam setiap satu rupiah total aset maka akan menghasilkan 0,0018 penjualan. Nilai maksimum sebesar 2,2546 artinya dalam setiap satu rupiah total aset maka akan menghasilkan 2,2546 penjualan. Nilai ratarata sebesar 0,7159 artinya setiap dana yang tertanam dalam aktiva rata-rata dalam satu tahun hanya berputar sebanyak 0,7159 kali penjualan. Nilai standar deviasi selama tahun 2011-2016 adalah sebesar 0,5123. Hal ini menunjukkan nilai rata-rata aktivitas lebih besar daripada nilai standar deviasi yang berarti kelompok data aktivitas dalam penelitian ini tidak bervariasi atau data berkelompok.

Pertumbuhan memiliki nilai minimum -0,9855 Nilai maksimum sebesar 33. Nilai rata-rata sales growth sebesar 0,4019. Nilai standar deviasi selama tahun 2011-2016 adalah sebesar 3,1596. Hal ini menunjukkan nilai rata-rata pertumbuhan lebih kecil daripada nilai standar deviasi yang berarti kelompok data pertumbuhan dalam penelitian ini bervariasi atau data menyebar.

Dewan direksi memiliki nilai minimum 2. Nilai maksimum sebesar 9. Nilai rata-rata dewan direksi sebesar 4,6389 atau berjumlah 4-5 orang dewan direksi. Nilai standar deviasi selama tahun 2011-2016 adalah sebesar 1,4988. Hal ini menunjukkan nilai rata-rata dewan direksi lebih besar daripada nilai standar deviasi yang berarti kelompok data dewan direksi dalam penelitian ini tidak bervariasi atau data berkelompok.

Komite audit memiliki nilai minimum 2. Nilai maksimum sebesar 7. Nilai rata-rata komite audit sebesar 3,2083 atau berjumlah 3 orang komite audit. Nilai standar deviasi selama tahun 2011-2016 adalah sebesar 0,7274 . Hal ini menunjukkan nilai rata-rata komite audit lebih besar daripada nilai standar deviasi yang berarti kelompok data komite audit dalam penelitian ini tidak bervariasi atau data berkelompok.

Tabel 3 menunjukkan hasil pengujian Hosmer and Lemeshow's, diperoleh nilai chi-square 4,517 dengan tingkat signifikansi 0.808 . Karena tingkat signifikansi hitung lebih besar dari 0,05 atau Sig $>\alpha(0,05)$, maka hipotesis nol diterima. Hal ini menunjukkan bahwa model dapat diterima sehingga pengujian hipotesis dapat diterima.

Tabel 4 menunjukkan -2LogL awal (-2LogL Block Number $=0$ ), dimana model hanya memasukkan konstanta menunjukkan nilai sebesar 173,935. Sedangkan nilai -2LogL pada langkah berikutnya $(-2$ LogL Block Number $=1)$, dimana model dimasukkan konstanta dan variabel independen menunjukkan nilai yang lebih kecil 143,806. Berdasarkan dari kedua hasil tersebut dapat disimpulkan bahwa terjadinya penurunan nilai -2Log Likelihood. Menurut Santoso (2014:219), apabila nilai -2Log Likelihood block number 0 lebih besar dari nilai -2Log Likelihood block number 1 maka menunjukkan model regresi yang semakin baik. Dengan demikian H0 diterima, sehingga model yang dihipotesiskan fit dengan data.

Tabel 5 menunjukkan hasil pengujian koefisien determinasi untuk mengukur seberapa jauh kemampuan variabel independen yang digunakan dalam model berpengaruh terhadap variabel dependen. Berdasarkan pengolahan data menggunakan regresi logistik, diperoleh nilai Cox and Snell R Square sebesar 0,188 dan nilai Nagelkerke R Square sebesar 0,269 yang berarti kombinasi antara likuiditas, aktivitas, pertumbuhan, dewan direksi dan komite audit mampu menjelaskan variasi dari kondisi financial distress sebesar 26,9\% dan sisanya dijelaskan oleh faktor-faktor lain yang tidak terlibat dalam penelitian ini.

Dari hasil pengujian regresi logistik pada Tabel 6 Omnibus Tests of Model Coefficients, diketahui bahwa nilai chi-square sebesar 30,041 dan degree of freedom sebesar 5, serta tingkat signifikansi atau p-value adalah sebesar 0,000 , yang artinya $(0,000<$ $0,05)$. Dengan demikian H01 ditolak dan Ha1 diterima, kondisi ini berarti bahwa variabel likuiditas, aktivitas, pertumbuhan, dewan direksi dan komite audit secara bersama-sama berpengaruh untuk memprediksi kondisi financial distress pada perusahaan.

Tabel 7 menunjukkan nilai p-value dari aktivitas adalah sebesar 0,020, dimana nilai tersebut lebih kecil jika dibandingkan dengan nilai signifikan $(\alpha)=5 \%$. Hal ini berarti terdapat pengaruh negatif yang signifikan antara aktivitas terhadap financial distress. 
Nilai p-value dari aktivitas adalah sebesar 0,000, dimana nilai tersebut lebih kecil jika dibandingkan dengan nilai signifikan $(\alpha)=5 \%$. Hal ini berarti terdapat pengaruh negatif yang signifikan antara aktivitas terhadap financial distress.

Nilai p-value dari pertumbuhan adalah sebesar 0,698, dimana nilai tersebut lebih besar jika dibandingkan dengan nilai signifikan $(\alpha)=5 \%$. Hal ini berarti tidak terdapat pengaruh yang signifikan antara pertumbuhan penjualan terhadap financial distress.

Nilai p-value dari dewan direksi adalah sebesar 0,278, dimana nilai tersebut lebih besar jika dibandingkan dengan nilai signifikan $(\alpha)=5 \%$. Hal ini berarti tidak terdapat pengaruh yang signifikan antara dewan direksi terhadap financial distress.

Nilai p-value dari komite audit adalah sebesar 0,742 , dimana nilai tersebut lebih besar jika dibandingkan dengan nilai signifikan $(\alpha)=5 \%$. Hal ini berarti tidak terdapat pengaruh yang signifikan antara komite audit terhadap financial distress. Berdasarkan hasil pengujian tersebut maka diperoleh persamaan model regresi sebagai berikut:

$$
\begin{aligned}
\mathrm{FD} & =1,594-0,513(\mathrm{CR}) 1,888(\mathrm{TATO})+0,025(\mathrm{SG}) \\
& -0,157\left(\text { Dew }_{\text {Dir }}\right)-0,099\left(\text { Kom }_{\text {Audit }}\right)+\mathrm{e}
\end{aligned}
$$

\section{Keterangan:}

$\begin{array}{ll}\text { CR } & \text { : Current Assets } \\ \text { TATO } & \text { : Total Assets Turnover } \\ \text { SG } & \text { : Sales Growth } \\ \text { Dew }_{\text {Dir }} & \text { : Dewan direksi } \\ \text { Kom }_{\text {Audit }} & \text { : Komite audit } \\ \text { e } & \text { : Error }\end{array}$

\section{PEMBAHASAN}

Berdasarkan hasil uji regresi logistik pada Tabel 6 dapat diketahui bahwa nilai koefisien regresi variabel likuiditas sebesar -0,513 dengan nilai signifikansi sebesar 0,020 . Hasil penelitian ini menyatakan bahwa likuiditas memiliki pengaruh negatif yang signifikan terhadap kondisi financial distress.

Likuiditas merupakan rasio yang terdiri dari aset lancar yang dibagi dengan hutang lancar. Rasio likuiditas (current ratio) berpengaruh negatif signifikan terhadap financial distress. Apabila perusahaan memiliki nilai likuiditas yang tinggi maka dapat dikatakan perusahaan tersebut dapat membayar kewajiban jangka pendeknya sehingga dapat terhindar dari masalah likuidasi ataupun kebangkrutan. Semakin tinggi likuiditas yang dimiliki perusahaan maka akan semakin kecil probabilitas perusahaan mengalami financial distress.

Hasil penelitian ini sesuai dengan hasil penelitian Hidayat dan Meiranto (2014) dan Cinantya dan Merkusiwati (2015) yang menunjukkan hasil bahwa likuiditas berpengaruh negatif signifikan terhadap kondisi financial distress, namun hasil pengujian dalam penelitian ini tidak sejalan dengan penelitian yang dilakukan oleh Aisyah (2017) yang menyatakan bahwa likuiditas tidak berpengaruh terhadap kondisi financial distress.

Berdasarkan hasil uji regresi logistik dapat diketahui bahwa nilai koefisien regresi variabel aktivitas sebesar $-1,888$ dengan nilai signifikansi sebesar 0,000 . Hasil penelitian ini menyatakan bahwa aktivitas memiliki pengaruh negatif signifikan terhadap kondisi financial distress.

Aktivitas (total assets turnover) berpengaruh negatif signifikan terhadap financial distress. Apabila perusahaan mampu memaksimalkan perputaran aset yang dimiliki perusahaan sehingga dapat menghasilkan penjualan yang maksimal maka probabilitas perusahaan mengalami kondisi financial distress akan menurun. Hal tersebut menunjukkan bahwa semakin tinggi aktivitas maka probabilitas perusahaan tersebut mengalami financial distress semakin kecil.

Hasil penelitian ini sesuai dengan hasil penelitian Hidayat dan Meiranto (2014) yang menunjukkan bahwa aktivitas berpengaruh negatif signifikan terhadap kondisi financial distress, namun hasil pengujian dalam penelitian ini tidak sejalan dengan penelitian yang dilakukan oleh Aisyah (2017) yang menyatakan bahwa aktivitas tidak berpengaruh terhadap kondisi financial distress.

Nilai koefisien regresi variabel pertumbuhan sebesar 0,025 dengan nilai signifikansi sebesar 0,698 . Hasil penelitian ini menyatakan bahwa pertumbuhan memiliki hubungan positif tidak signifikan terhadap kondisi financial distress.

Hasil yang tidak signifikan dalam penelitian ini disebabkan oleh adanya regulasi pemerintah yaitu PP No 1 tahun 2014 yang membatasi penjualan bahan mentah hasil tambang. Regulasi tersebut pada akhirnya menyebabkan terjadinya keterbatasan perusahaan dalam melakukan penjualan.

Karena hal tersebut berdampak pula pada rendahnya beban yang dikeluarkan perusahaan untuk menghasilkan penjualan sehingga peningkatan penjualan yang terjadi pada perusahaan tambang juga menjadi rendah. Oleh karena itu, rendahnya penjualan yang terjadi pada perusahaan tambang tidak serta merta dapat dijadikan acuan bahwa perusahaan tersebut dapat mengalami kondisi financial distress. Apabila perusahaan memiliki penjualan tinggi dengan beban-beban yang dikeluarkan terus menerus tinggi sehingga pendapatan yang dihasilkan sedikit hal tersebut juga dapat memungkinkan perusahaan mengalami kondisi financial distress.

Hasil penelitian ini sesuai dengan hasil penelitian Liana dan Sutrisno (2014) yang menunjukkan hasil bahwa pertumbuhan tidak berpengaruh terhadap kondisi financial distress, namun hasil pengujian dalam penelitian ini tidak sejalan dengan penelitian yang dilakukan oleh Eliu (2014) yang menyatakan bahwa pertumbuhan berpengaruh signifikan terhadap kondisi financial distress. 
Nilai koefisien regresi dewan direksi sebesar - 0,157 dengan nilai signifikansi sebesar 0,278 . Hasil penelitian ini menyatakan bahwa dewan direksi memiliki hubungan negatif tidak signifikan terhadap kondisi financial distress.

Dewan direksi diukur menggunakan jumlah dewan direksi. Dewan direksi merupakan salah satu mekanisme yang sangat penting dalam corporate governance, dimana keberadaannya menentukan kinerja perusahaan. Jumlah anggota dewan direksi harus disesuaikan dengan kompleksitas dan kebutuhan perusahaan. Namun, pada penelitian ini menunjukkan dewan direksi tidak berpengaruh terhadap kondisi financial distress. Hasil tersebut dapat dikarenakan oleh adanya faktor lain yang mempengaruhi, yaitu tentang Undang-Undang Nomor 40 Tahun 2007 tentang Perseroan Terbatas pada pasal 92 ayat (4) menyebutkan bahwa Rapat Umum Pemegang Saham (RUPS) menetapkan pembagian tugas dan wewenang pengurusan di antara anggota direksi dalam hal direksi terdiri atas dua anggota direksi atau lebih, sehingga masih ada keterbatasan wewenang direksi.

Oleh karena itu, tinggi atau rendahnya jumlah dewan direksi tidak mempengaruhi kondisi financial distress. Kondisi suatu perusahaan sebenarnya diketahui oleh para dewan direksi, namun keputusan tetap diambil pada Rapat Umum Pemegang Saham (RUPS). Hal ini juga yang dapat menyebabkan berapapun jumlah dewan direksi pada suatu perusahaan tidak mempengaruhi probabilitas terjadinya kondisi financial distress.

Hasil penelitian ini sesuai dengan hasil penelitian Cinantya dan Merkusiwati (2015) yang menunjukkan hasil bahwa dewan direksi tidak berpengaruh terhadap kondisi financial distress, namun hasil pengujian dalam penelitian ini tidak sejalan dengan penelitian yang dilakukan oleh Setiawan, et. al. (2014) yang menyatakan bahwa dewan direksi berpengaruh signifikan terhadap kondisi financial distress.

Nilai koefisien regresi variabel komite audit sebesar 0,099 dengan nilai signifikansi sebesar 0,742. Hasil penelitian ini menyatakan bahwa komite audit memiliki hubungan positif tidak signifikan terhadap kondisi financial distress.

Komite audit diukur menggunakan jumlah komite audit. Komite audit merupakan salah satu mekanisme yang sangat penting dalam corporate governance, karena diasumsikan mampu mengurangi masalah keagenan yang timbul pada suatu perusahaan. Efektivitas komite audit akan meningkat jika ukuran komite audit meningkat, karena komite memiliki sumber daya lebih untuk menangani masalah-masalah yang dihadapi oleh perusahaan. Namun, pada penelitian ini menunjukkan komite audit tidak berpengaruh terhadap kondisi financial distress. Hasil tersebut dapat dikarenakan oleh adanya faktor lain yang mempengaruhi, yaitu tentang Peraturan Otoritas Jasa Keuangan Nomor 55/ POJK.04/2015 pasal 1 ayat (4) menyebutkan komite audit paling sedikit terdiri dari 3 (tiga) orang anggota yang berasal dari komisaris independen dan pihak dari luar emiten atau perusahaan publik agar dapat melaksanakan pengawasan perusahaan secara efektif. Hasil statistik deskriptif menunjukkan mayoritas perusahaan memiliki jumlah komite audit sebanyak 3 orang. Oleh karena itu, jumlah komite audit di bawah rata-rata tidak dapat mengindikasikan perusahaan mengalami kondisi financial distress.

Hasil penelitian ini sesuai dengan hasil penelitian Mayangsari (2015) yang menunjukkan hasil bahwa komite audit tidak berpengaruh terhadap kondisi financial distress, namun hasil pengujian dalam penelitian ini tidak sejalan dengan penelitian yang dilakukan oleh Rahmat, et. al. (2008) yang menyatakan bahwa dewan direksi berpengaruh signifikan terhadap kondisi financial distress.

\section{KESIMPULAN}

Likuiditas pada perusahaan pertambangan yang terdaftar di Bursa Efek Indonesia tahun 2011-2016 mempunyai nilai rata-rata sebesar 1,9277 dan standar deviasi sebesar 1,3382. Aktivitas mempunyai nilai ratarata sebesar 0,7159 dan standar deviasi sebesar 0,5123. Pertumbuhan mempunyai nilai rata-rata sebesar 0,4019 dan standar deviasi sebesar 3,1596. Dewan direksi mempunyai nilai rata-rata sebesar 4,6389 dan standar deviasi sebesar 1,4988 . Komite audit mempunyai nilai rata-rata sebesar 3,2083 dan standar deviasi sebesar 0,7274.

Likuiditas, aktivitas, pertumbuhan, dewan direksi dan komite audit secara bersama-sama berpengaruh terhadap kondisi financial distress pada perusahaan pertambangan yang terdaftar di BEI periode 20112016. Secara parsial pertumbuhan, dewan direksi, dan komite audit tidak berpengaruh signifikan, sedangkan likuiditas dan aktivitas berpengaruh signifikan.

\section{DAFTAR PUSTAKA}

Aisyah, M., 2017. Consumers demand on Halal cosmetics and personal care products in Indonesian. Journal of Islamic Economics, 9(1), pp.125-142.

Andriyanto, C., Sudarto, S. and Suprayogo, D., 2015. Estimation of soil erosion for a sustainable land use planning: RUSLE model validation by remote sensing data utilization in the Kalikonto watershed. Journal of Degraded and Mining Lands Management, 3(1), pp.459-468.

Bringham, E.F. and Houston, J.F., 2010. Essentials of Financial Management: Dasar-Dasar Manajemen Keuangan. Penerjemah Ali Akbar Yulianto. Edisi Kesebelas. EdisiIndonesia. Buku I. Jakarta: Salemba Empat.

Cinantya, \& Merkusiwati. 2015. Pengaruh Corporate Governance, Financial Indicators, dan Ukuran Perusahaan Pada Financial distress. E-Jurnal 
Akuntansi Universitas Udayana 10.3 ISSN: 23028556, 3, 897-915.

Djumena, E., 2015. Sensus Pajak Nasional.

Eliu, Viggo. 2014. Pengaruh Financial Leverage dan Firm Growth Terhadap Financial distress. Finesta, Volume 2, Nomor 6-11.

Fahmi, I. 2012. Analisis Laporan Keuangan. Penerbit Alfabeta. Bandung.

Hamdani 2017. Masih saja rugi bumi resources tak bagi dividen. Retrieved from https://economy.okezone. com.

Hermawan, M. and Mulyawan, S., 2013. Profitability and Corporate Social Responsibility: An Analysis of Indonesia's Listed Company.

Hidayat, M.A. and Meiranto, W., 2014. Prediksi Financial distress Perusahaan Manufaktur di Indonesia (Studi Empiris pada Perusahaan Manufaktur yang Terdaftar di Bursa Efek Indonesia Periode 2008-2012) (Doctoral dissertation, Fakultas Ekonomika dan Bisnis).

Liana, D., Sutrisno., 2014, Analisis Rasio Keuangan Untuk Memprediksi Kondisi Financial distress Perusahaan Manufaktur. Jurnal Studi Manajemen dan Bisnis, 1(2), pp.52-56.

Mayangsari, L. Putri. 2015. Pengaruh Good Corporate

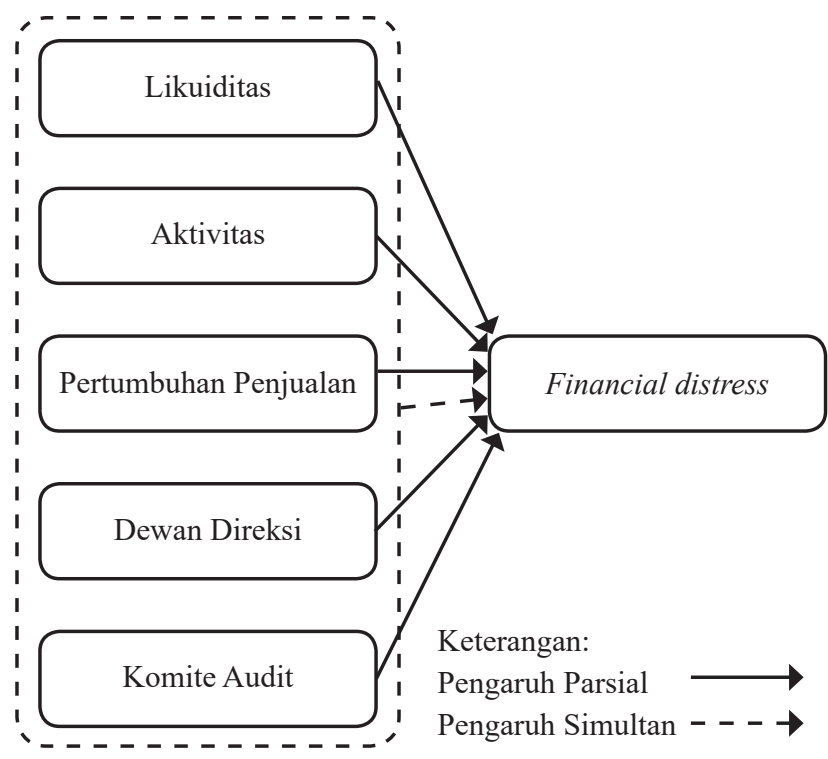

Gambar 1. Kerangka Pemikiran
Governance Dan Kinerja Keungan Terhadap Financial distress. Jurnal Ilmu Dan Riset Akuntansi Volume 4 No 4, 4(4).

Platt, H.D and Platt, M.B. 2002. Predicting Corporate Financial distress: Reflections on choice-based sample bias. Journal of Economics and Finance Volume 26, 26, 184-199.

Rahmat et al. 2008. Audit Committee Characteristics in Financially Distressed and non-Distressed Companies. Managerial Auditing Journal Volume 24 Nomor 7. Pp. 624-638, 24.

Setiawan, P.Y., Troena, E.A. and Armanu, N., 2014. The effect of e-WOM on destination image, satisfaction and loyalty. International Journal of Business and Management Invention, 3(1), pp.22-29.

Whitaker, R. 1999. The Early Stage of Financial distress. Journal of Economics and Fianance. Volume 23, Number 2. Summer1999. Pages 123133, 23, 123-133.

Widhiari, N.L \& Merkusiwati, N.K. 2015. Pengaruh Rasio Likuiditas, Leverage, Operating Capacity, dan Sales Growth Terhadap Financial distress, 2 , 456-469.

Zarkasyi, Moh. Wahyudi. 2008. Good Corporate Governance. Jakarta: Alfabeta.

Tabel 1. Operasionalisasi Variabel

\begin{tabular}{|c|c|c|c|}
\hline Variabel & Sumber & Indikator & Skala \\
\hline \multirow{2}{*}{$\begin{array}{l}\text { Likuiditas } \\
\left(\mathrm{X}_{1}\right)\end{array}$} & \multirow{2}{*}{$\begin{array}{l}\text { Fahmi } \\
\text { 2012:59 }\end{array}$} & Aktiva Lancar & \multirow[t]{2}{*}{ Rasio } \\
\hline & & $\mathrm{Cr}=\mathrm{Utang}$ Lancar & \\
\hline \multirow{2}{*}{$\begin{array}{l}\text { Aktivitas } \\
\left(\mathrm{X}_{2}\right)\end{array}$} & \multirow{2}{*}{$\begin{array}{l}\text { Fahmi } \\
\text { 2012:65 }\end{array}$} & Sales & \multirow[t]{2}{*}{ Rasio } \\
\hline & & Total Asset & \\
\hline \multirow{2}{*}{$\begin{array}{l}\text { Pertumbuhan } \\
\left(\mathrm{X}_{3}\right)\end{array}$} & \multirow{2}{*}{$\begin{array}{l}\text { Fahmi } \\
\text { 2012:67 }\end{array}$} & sales $(t)$-sales $(t-1)$ & \multirow[t]{2}{*}{ Rasio } \\
\hline & & $\operatorname{sales}(t-1)$ & \\
\hline $\begin{array}{l}\text { D e w a n } \\
\text { direksi }\left(X_{4}\right)\end{array}$ & $\begin{array}{l}\text { Hamdani } \\
\text { 2016:86 }\end{array}$ & Jumlah dewan direksi & Rasio \\
\hline $\begin{array}{l}\text { Komite audit } \\
\left(\mathrm{X}_{5}\right)\end{array}$ & $\begin{array}{l}\text { Zarkasyi, } \\
\text { 2008:17). }\end{array}$ & Jumlah komite audit & Rasio \\
\hline $\begin{array}{l}\text { Financial } \\
\text { distress }(\mathrm{Y})\end{array}$ & $\begin{array}{l}\text { Fathi } \\
\text { Elloumi } \\
\text { Jean and } \\
\text { Pierre } \\
\text { Gueyié, } \\
2001\end{array}$ & $\begin{array}{l}\text { - Nilai } 1 \text { menunjukkan } \\
\text { kondisi financial } \\
\text { distress (eps negatif). } \\
\text { - Nilai } 0 \text { menunjukkan } \\
\text { kondisitidak mengalami } \\
\text { financial distress (eps } \\
\text { positif). }\end{array}$ & Nominal \\
\hline
\end{tabular}


Tabel 2. Hasil Pengujian Statistik Deskriptif

\begin{tabular}{lrrrrr}
\hline \multicolumn{5}{c}{ Statistik Deskriptif } \\
\hline & Likuiditas & Aktivitas & $\begin{array}{c}\text { Pertum- } \\
\text { buhan }\end{array}$ & $\begin{array}{r}\text { Dewan } \\
\text { Direksi }\end{array}$ & $\begin{array}{c}\text { Komite } \\
\text { Audit }\end{array}$ \\
\hline Min & 0,0524 & 0,0018 & $-0,9855$ & 2 & 2 \\
Max & 10,6423 & 2,2546 & 33,9789 & 9 & 7 \\
Mean & 1,9277 & 0,7159 & 0,4019 & 4,6389 & 3,2083 \\
Std. & 1,3382 & 0,5123 & 3,1596 & 1,4988 & 0,7274 \\
Deviasi & & & & & \\
\hline
\end{tabular}

Sumber : Data sekunder yang diolah, 2017

Tabel 3. Hosmer and Lemeshow Test

\begin{tabular}{cccc}
\hline Step & Chi-square & Df & Sig. \\
\hline 1 & 4,517 & 8 &, 808 \\
\hline
\end{tabular}

Sumber: Hasil output Spss versi 23 (2017)

Tabel 4. Overall Model Fit

\begin{tabular}{cc}
$\frac{\text { Tabel 4. Overall Model Fit }}{\text { Overall model fit }(-2 \operatorname{LogL})}$ \\
\hline -2LogL Block Number $=0$ & Nilai 173,935 \\
-2LogL Block Number $=1$ & Nilai 143,086 \\
\hline Sumber: Hasil output Spss versi 23 (2017)
\end{tabular}

Tabel 5. Model Summary

\begin{tabular}{|c|c|c|c|c|}
\hline Step & $\begin{array}{c}-2 \log \\
\text { Likelihood }\end{array}$ & $\begin{array}{c}\text { Cox \& Snell R } \\
\text { Square }\end{array}$ & & $\begin{array}{c}\text { Nagelkerke R } \\
\text { Square }\end{array}$ \\
\hline 1 & $143,806^{\mathrm{a}}$ & , 188 & & ,269 \\
\hline \multicolumn{5}{|c|}{ Sumber: Hasil output Spss versi 23 (2017) } \\
\hline \multicolumn{5}{|c|}{ Tabel 6. Omnibus Tests of Model Coefficients } \\
\hline & & Chi-square & Df & Sig. \\
\hline \multirow[t]{3}{*}{ Step 1} & Step & 30,041 & 5 &, 000 \\
\hline & Block & 30,041 & 5 &, 000 \\
\hline & Model & 30,041 & 5 &, 000 \\
\hline
\end{tabular}

Sumber: Hasil output Spss versi 23 (2017)

Tabel 7. Variables in the Equation

\begin{tabular}{|c|c|c|c|c|c|c|c|}
\hline Step $1^{\mathrm{a}}$ & & B & S.E. & Wald & Df & Sig. & $\operatorname{Exp}(B)$ \\
\hline \multirow[t]{9}{*}{ Step $1^{\mathrm{a}}$} & $\mathrm{CR}$ &,- 513 & ,220 & 5,433 & 1 & ,020 & ,599 \\
\hline & TATO & $-1,888$ & ,501 & 14,191 & 1 &, 000 & ,151 \\
\hline & Sales & ,025 & ,065 & ,151 & 1 & 698 & 1,025 \\
\hline & Growth & & & & & & \\
\hline & Dewan &,- 157 & ,144 & 1,178 & 1 & ,278 & ,855 \\
\hline & Direksi & & & & & & \\
\hline & Komite & ,099 & ,300 & , 108 & 1 & ,742 & 1,104 \\
\hline & Audit & & & & & & \\
\hline & Constant & 1,592 & 1,109 & 2,061 & 1 &, 151 & 4,914 \\
\hline
\end{tabular}

Sumber: Hasil output Spss versi 23 (2017) 